\title{
What Signals Operate in the Mammary Niche?
}

\author{
Tamara Tanos and Cathrin Brisken* \\ NCCR Molecular Oncology, Ecole polytechnique fédérale de Lausanne (EPFL), ISREC - Swiss Institute for \\ Experimental Cancer Research, 155, Chemin des Boveresses, CH-1066 Epalinges, Switzerland
}

\begin{abstract}
Adult stem cells reside in a specialized microenvironment, the niche, which controls their behavior. As mammary stem cells, and consequently their niches, are still poorly defined, we look at better-characterized adult mammalian stem cell niches in the hematopoietic system and the skin. We attempt to define the mammary stem cell niche functionally, based on the widely used mammary fat pad reconstitution assay.

We note that the concept of the niche needs to be extended from the specialized microenvironment described in the hematopoietic system, to a model that takes into account the macroenviroment, as recently shown in the skin, and systemic clues as we will illustrate for the mammary gland where the reproductive hormones are major determinants of stem cell activation. In fact, in the mammary gland a special type of stem cells is determined only during pregnancy.

Reproductive hormones act on hormone receptor positive cells, sensor cells, in the mammary epithelium to induce paracrine signaling that leads to activation of stem cells. Some of the downstream mediators are in common with other niches such as Wnt and possibly Notch signaling. Other signals are specific to the mammary gland such as amphiregulin and RANKL.
\end{abstract}

Keywords: Estrogens, progesterone, mammary gland, stem cell niche, microenvironment, macroenvironment

\section{INTRODUCTION}

The breast undergoes most of its development after birth under the control of systemic hormones. Reproductive hormones are messengers of systemic requirements to the mammary gland tissue and orchestrate major changes in this organ by modulating local signaling pathways $[15,41]$.

The rudimentary ductal system present at birth begins to expand during puberty. With repeated menstrual cycles, its complexity increases. The most dramatic increase in epithelial cell number occurs during pregnancy. Throughout lactation there is little cell proliferation; in the absence of breastfeeding or after weaning, the breast involutes and returns to a state that morphologically resembles a pre-pregnancy gland. With every new pregnancy this cycle is repeated; this seeming-

*Corresponding author. Tel.: +4121692 58 51; Fax: +4121652 69 33; E-mail: cathrin.brisken@epfl.ch. ly unlimited regeneration capacity is attributed to the presence of breast epithelial stem cells.

Adult stem cells are capable of self-renewal and can give rise to differentiated cell lineages. In the breast two cell lineages are distinguished; the luminal cells that line the lumen and thereby form a tube and the contractile myoepithelial cells that form a meshwork around the luminal cells.

Studying the hematopoeitic system, Schofield first recognized that stem cells do not operate in isolation but depend on their microenvironment; he coined the term "niche" for the microanatomical space that is formed by neighboring cells that allows only one stem cell to fit in and maintains the self-renewal capacity of this cell [94]. As a stem cell divides, one cell has to leave the niche; it may still be multipotent but has less self-renewal capacity than the cell that remains in the niche [37,133]. A cell that has left the niche but finds an empty niche and homes to it can reacquire stem cell properties [45, 82].

The concept of the niche has since been confirmed experimentally in Drosophila melanogaster and 
Caenorhabditis elegans [62]; stem cells and their niches have been well characterized for instance in the drosophila gonads and midgut [26,51,70,135].

In mammals, adult stem cells have been mapped in few tissues. Schofield had hypothesized that the niche for hematopoietic stem cells is at the interface with the bone in the bone marrow and indeed, hematopoietic stem cells (HSCs) have been identified there, either next to immature osteoblasts or next to fenestrated endothelial cells [20,139]. Epidermal stem cells are found in the bulge area of hair follicles [25], the crypt was identified as the location for intestinal stem cells [6], and in the brain, stem cells are in the subventricular zone [55].

The identity and localization of mammary epithelial stem cells is still debated, consequently, the niche components remain to be defined. Here, we take a look at what is known about mammalian adult stem cell niches in different tissues and the signaling that occurs within them. We will speculate about the composition of the mammary stem cell niche and discuss potential signals operating between niche and stem cells.

\section{STEM CELL NICHES: DIFFERENT LEVELS OF CONTROL}

\section{Hematopoietic niche}

The best-characterized adult stem cell is the hematopoietic stem cell $[127,133]$; murine HSCs were identified based on their ability to provide reconstitution of all blood cell lineages in lethally irradiated mice [7, 117,134]. Adult HSCs home to two niches in the bone marrow, the endosteal one, in which they physically interact with a subset of immature osteoblasts [3,79], and the vascular one (Fig. 1) [59,118], in which they attach to the fenestrated endothelial cells of bone marrow sinusoids $[113,114]$. The endosteal zone favors quiescence, whereas the vascular niche is thought to allow differentiation and ultimately mobilization to the circulation [54].

Experiments with genetically engineered mice showed that activation of parathyroid receptor 1 (PTH1R) signaling as well as ablation of the bone morphogenetic protein (BMP) receptor (BMPR1A) signaling in the bone-marrow stroma resulted in an increase in both the number of osteoblasts and HSCs in the bone marrow [20,139] and revealed the role of immature osteoblasts as central components of the niche.

Osteoblasts secrete and/or activate factors (Fig. 2) such as angiopoietin, stem cell factor (SCF) and the

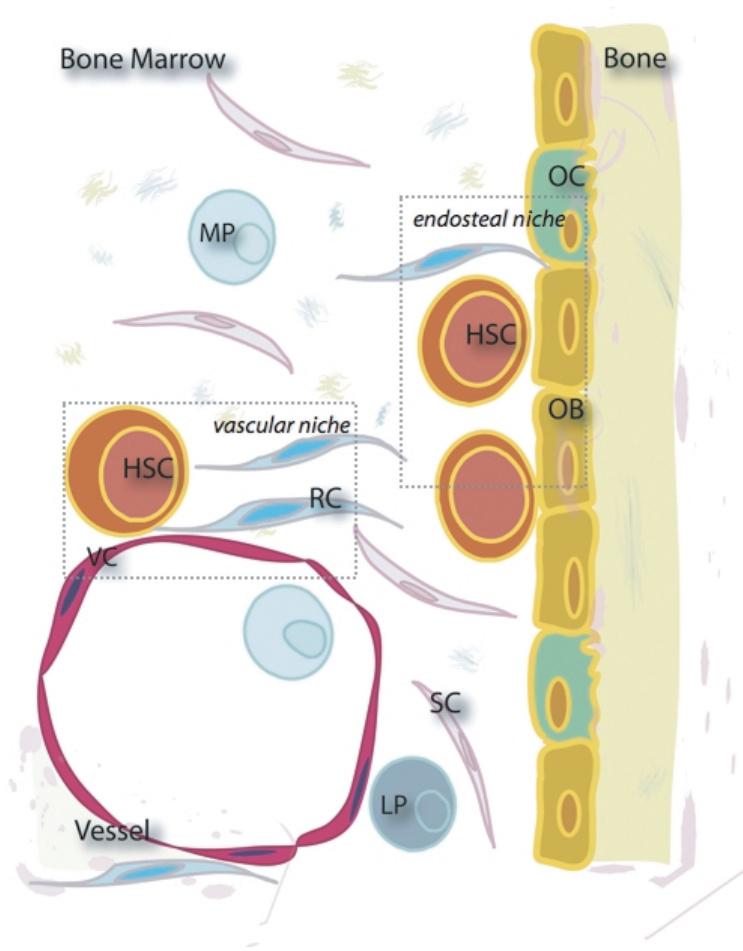

Fig. 1. Hematopoetic Stem Cell Niche.Schematic representation of the endosteal and perivascular hematopoietic stem cell niches and their cellular components. HSC: hematopoietic stem cell; OB: immature osteoblast; OC: osteoclast; RC: reticular cell; VC: sinusoid vascular cell. MP: myeloid precursor; LP: lymphocyte precursor.

matrix acid glycoprotein, osteopontin $[1,80]$ which activate their respective receptors Tie2, c-Kit, and CD44, on HSCs. Tie2/Ang-1 and KIT signaling maintain HSCs quiescent ensuring their self-renewal capacity [1, $66,116]$. Osteopontin, recognized by $\beta 1$-integrin on the HSCs' membrane physically sequesters HSCs in the niche thereby indirectly inhibiting HSC proliferation $[80,105]$.

Reticular cells are specialized fibroblasts that constitute the vascular niche and contribute to the endosteal niche; they express CXCL12/SDF-1 (stromal cell-derived factor-1) that binds to the chemokine receptor CXCR4 on the HSCs membrane. This interactions and the resulting signaling are required to maintain HSCs in vascular niches [110].

A central signaling pathway in self-renewal and differentiation of HSCs is canonical Wnt signaling. Constitutive activation of this signaling cascade blocks differentiation and leads to accumulation of functionally defective HSCs $[53,92]$. Ectopic expression of the secreted Wnt antagonist dickkopf-1 (Dkk-1) in niche cells results in a failure to maintain HSCs quiescent and consequent loss of self-renewal ability [109]. On the other 


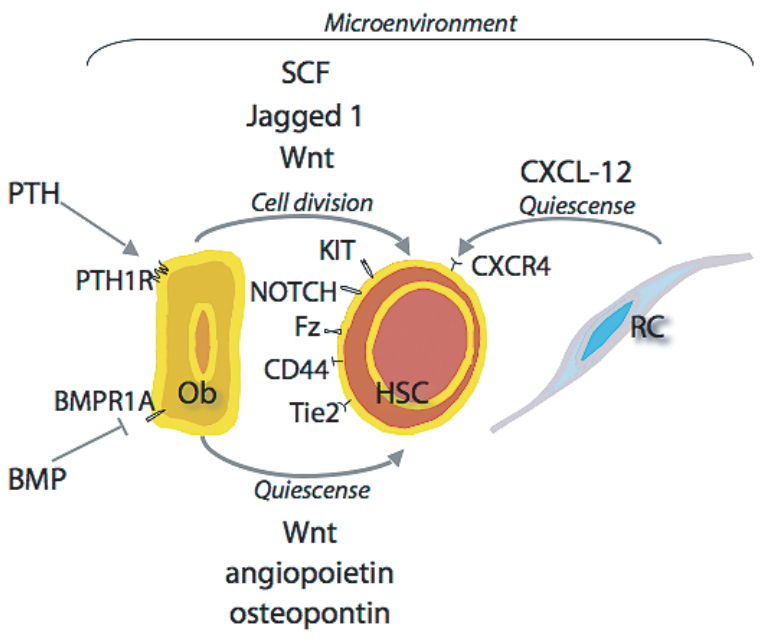

Fig. 2. Hematopoetic Stem Cell Niche. The scheme shows the signaling molecules and their receptors in the HSC that regulate HSC behaviour; SCF/KIT, Jagged1/Notch and Wnt/Fz are involved in osteoblast induced cell renewal; osteopontin/CD44; angiopoietin/Tie2 and also $\mathrm{Wnt} / \mathrm{Fz}$ are involved in osteoblast induced quiescence of the stem cells and CXCL-12/CXCR4 in reticulocyte induced quiescence. Both PTH/PTH1R stimulation and BMP/BMPR1A downregulation leads to an increase in obsteoblast number and consequently in the HSC number. HSC: hematopoietic stem cell; OB: immature osteoblast; RC: reticular cell.

hand activation of the Wnt signaling pathway increases the ability of HSCs to reconstitute the hematopoietic system of irradiated mice [87]. Wnt-5a which activates noncanonical and inhibits canonical Wnt signaling maintaining HSCs in a quiescent state [76]. Taken together, these somewhat contradictory data suggest that canonical Wnt signaling has an important role in controlling the stem cell pool, however, the biological consequences of activating this signaling cascade are dose and stage-dependent.

Notch signaling has been implicated in the control of the HSC pool as ectopic activation of this pathway results in an increased number of HSCs $[49,104]$. Consistent with a role of Notch signaling in hematopoesis, both receptors and ligands are expressed in the bone marrow [85]. However, loss-of-function experiments suggest that the pathway is not essential [68].

Loss of the transcription factor c-myc in HSCs increases the expression of cell adhesion proteins in stromal cells that seemingly retain HSCs in an extended niche resulting in decreased HSC differentiation [5, 132].

\section{Epidermal niche $(s)$}

Another organ system amenable to functional studies is the skin; it comprises multilayered interfollicu- lar epidermis (IFE) and different appendages, such as hair follicles, sweat glands and sebaceous glands [9] (Fig. 3). Epidermal stem cells are found in the IFE, in the sebaceous glands and in the bulge region of the hair follicle; stem cells of the bulge region have been isolated and have been shown to reconstitute all epidermal compartments $[46,115]$ and will be discussed here. In the bulge, stem cells can interact with surrounding epithelial cells, the inner and outer root sheath cells, as well as with the basement membrane and fibroblasts (Fig. 3). To what extent these different interactions are important to stem cell function is currently a matter of debate.

The surface protein, $\beta 1$-integrin, used by HSCs to bind osteopontin, mediates binding to the basal membrane component laminin and collagen in epithelial cells and is enriched in epidermal stem cells versus more differentiated populations [48,65]. It is functionally important as blocking $\beta 1$-integrin by ectopic expression of a dominant negative mutant results in differentiation [140].

The transcription factor p63 is essential for the establishment of stratified epithelia $[72,136]$. Whether it has a role in stem cell maintenance like in the thymus [21, 95] or whether it is required for the commitment to stratification is debated [56,57]. Interestingly, p63 is downregulated by activation of Notch signaling in suprabasal cells [78]. In contrast to its stimulatory effects in the stem cell compartment of the hematopoietic system, Notch stimulates differentiation in the skin [86].

Overexpression of the transcription factor c-myc promotes differentiation of stem cells $[2,126]$ suggesting that its role in the skin is different from its role in the hematopoietic system. However, loss-of-function experiments are required to draw this conclusion.

Central to activation of bulge stem cells is periodic activation of canonical Wnt signaling [42,111,120]. Upon elevation of the levels of $\beta$-catenin hair follicles enter anagen (phase of rapid proliferation) [64,121] whereas Wnt signaling is suppressed during telogen (phase of mitotic quiescence, regression phase) [31, 84]. Expression of the bone morphogenetic proteins (BMPs)-2 and -4 in the dermis and subcutaneous fat cycles out of phase with respect to this recurrent Wnt signaling activation [84]. High BMP signaling activity keeps the hair follicle refractory whereas low BMP signaling activity renders it competent for regeneration [84]. Thus, stem cell activity is not only influenced by the microenvironment but ultimately controlled by signaling from another organ; Plikus and colleagues introduced the term "macroenvironment" to describe this long distance signaling. 


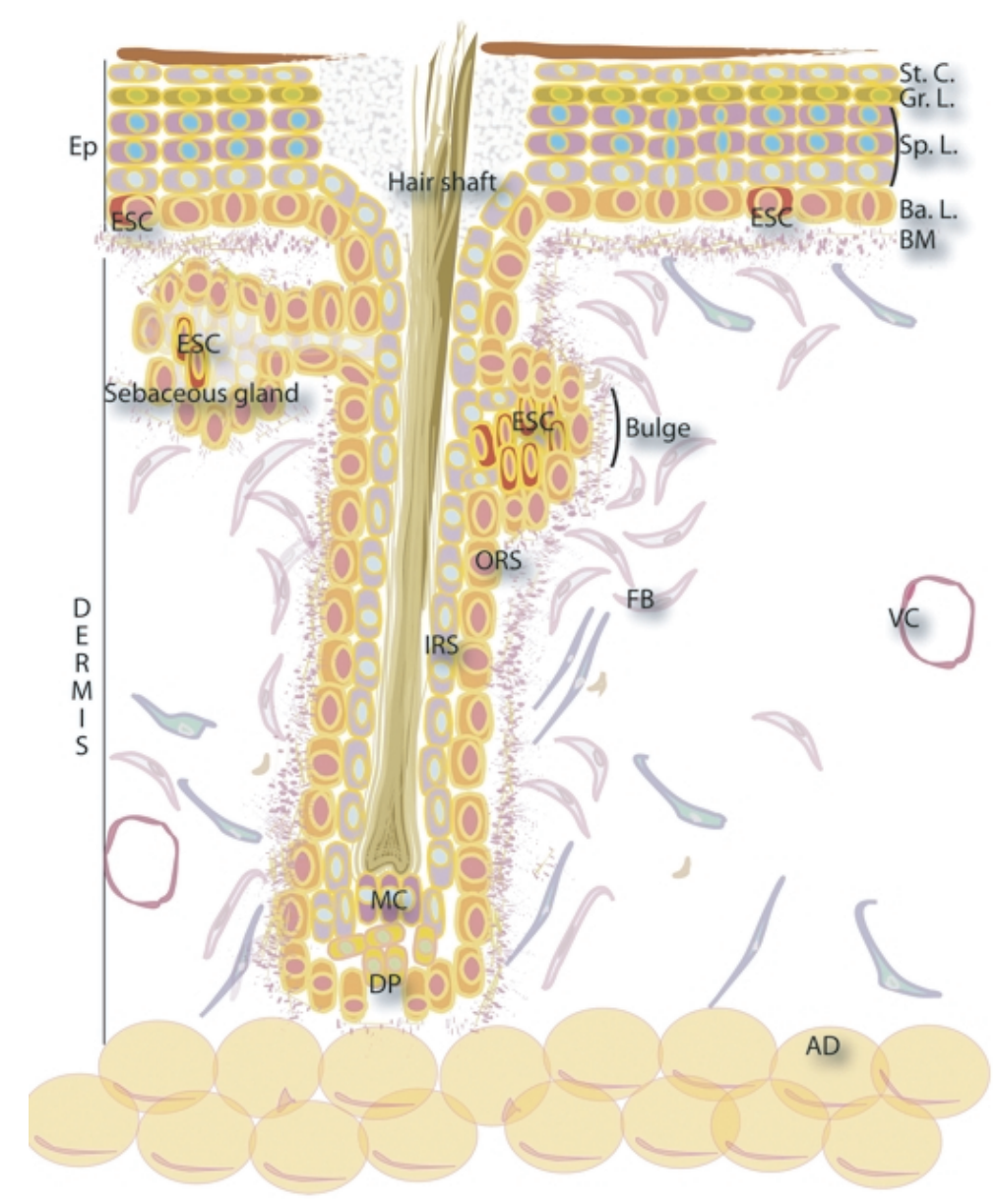

Fig. 3. Epidermal Stem Cell Niche. Schematic diagram of the skin and its cellular components. EP: epidermis, ESC: epidermal stem cell; MC: matrix cells; DP: Dermal papilla; FB: fibroblast; AD: adipocyte; VC: Vascular Cell Ba.L.: basal cells layer; BM: basement membrane; ORS: outer root sheath; IRS: inner root sheath; St.C.: stratum corneum; Gr. L.: granular layer; Sp. L.: spinous layer.

\section{BREAST EPITHELIAL STEM CELLS AND THEIR NICHE}

As breast epithelial stem cells can give rise to myoepithelial and luminal cells, it has been surmised that stem cells express markers of both the luminal and myoepithelial cell lineage [83,106,107]. Cells co-expressing both type of markers have been identified; they are located in an intermediate position between the myoepithelial and luminal cells in the human breast [39]. These cells are epithelial and hence express the panepithelial marker EpCAM but they do not express proteins found on the apical membrane of differentiated luminal cells, such as MUC1. Such cells were purified from reduction mammoplasty specimens. Consistent with being bipotential progenitors, the MUC-/ESA+ cells gave rise to both luminal and myoepithelial cell types in $2 \mathrm{D}$ and $3 \mathrm{D}$ cultures [39]. However, in vitro cultures have limitations; for example hormone receptor expression does not occur and it remains to be shown that these populations reconstitute in vivo. More recently, a stem cell zone has been localized in the ducts based on inmunohistochemistry assays for putative stem cell and niche markers [123].

In rodents, reconstitution of epithelium-divested mammary fat pads provides a functional assay for stem cells $[27,32,137]$. In 3-week-old prepubertal mice the inguinal mammary gland can be surgically cleared of the endogenous epithelium. Any part of the mammary gland is able to give rise to a new ductal system when grafted to such a cleared fat pad $[81,137]$ independently of age, reproductive history or reproductive state of the donor mice [30]. The reconstitution ability is lost over seven consecutive transplant generations [27].

The reconstitution of the cleared fat pad by engrafted mammary epithelial cells (MECs) has been 


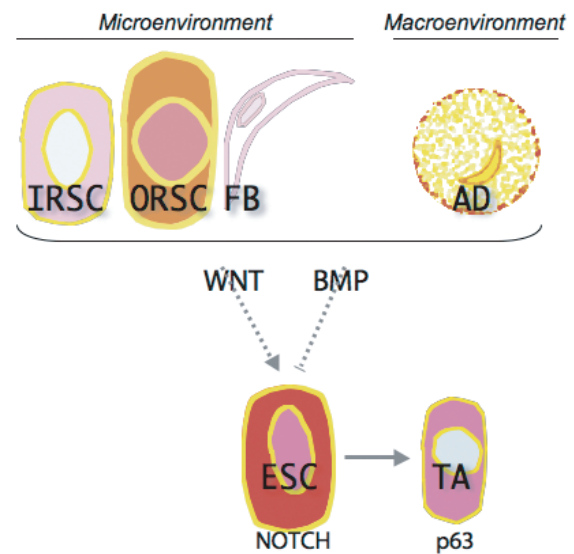

Fig. 4. Epidermal Stem Cell Niche. Schematic representation of the signaling pathways that regulate epidermal stem cell behavior in the hair bulge region. Out of phase waves of Wnt and BMP signaling induce proliferation or maintain quiescence respectively. ESC: epidermal stem cell; FB: fibroblast; AD: adipocyte; ORSC: outer root sheath cell; IRSC: inner root sheath cell; TA: transient amplifying cell.

very successfully used as an assay for stem cell activity combined with immunophenotyping and fluorescence activated cell sorting (FACS) of MECs [69, $96,108,128]$. This line of work revealed subpopulations of MECs with distinct reconstitution potential. Cells with high reconstitution potential are enriched in a population expressing the glycosyl phosphatidylinositol (GPI)-anchored protein CD24 and high levels of $\beta 1$ (CD29) and $\alpha 6$ (CD49) integrin (CD24 ${ }^{+}$CD29high CD49high $)[96,108]$.

Consistent with the role of integrins in binding ECM components, these surface molecules are highly expressed in cells that interact with the basal lamina [93]. Indeed, cells in the CD24 ${ }^{+}$CD $49^{\text {high }}$ CD29 $9^{\text {high }}$ compartment bear myoepithelial characteristics; they express Keratin 14 [96,108], high levels of the epidermal growth factor receptor (EGFR), and do not express the estrogen receptor $\alpha(\mathrm{ER} \alpha)$ [4]. Taken together, these observations suggest that the mammary stem cells localize basally within the mammary epithelium, possibly with extensive direct contact to the basal lamina.

Previous studies based on morphological characteristics had attributed a particular phenotype to stem cells. Based on their appearance by electron microscopy or by toluidine blue stain on ultrathin sections, they were called "small light cells" (SLC) [22,99]. SLCs are found dispersed in an intermediate position between luminal and myoepithelial cells like the bipotential progenitor cells in the human breast described above [22, 99]. The SLCs were shown to be the only cells that enter mitosis when mammary explants were cultured [99].
Consistent with these cells being stem cells, their numbers decrease as the reconstitution potential of mammary epithelium diminishes upon serial transplantation [99].

These two lines of work point to two different scenarios for the localization of mammary stem cells (Fig. 5): in the first, the mammary stem cell is part of the myoepithelial sheet; in the second scenario, the mammary stem cell is located between the luminal and myoepithelial layers. These two models may not be mutually exclusive; the morphologically defined SLCs may express the same surface markers as the myoepithelial cells and therefore part of the CD24 $4^{\text {low } / C D 29 \text { high }}$ and CD $49^{\text {high }}$ population in FACS sorting. Alternatively, light cells may simply contaminate the FACS sorted population; obviously, even a single contaminating stem cell should, by definition, reconstitute a mammary gland.

While SLCs represent around 3\% of the epithelial cell population [22] estimates of stem cell frequency based on FACS sorting vary between different group from 1 in 200 [73] to 1 in 5000 MECs [96].

\section{A FUNCTIONAL DEFINITION OF THE MAMMARY STEM CELL NICHE}

In both the scenarios presented above (Fig. 5), the microenvironment of the putative stem cell comprises neighboring luminal and myoepithelial cells as well as more or less extensive contact with the basal lamina. Based on the functional definition of a stem cell by the reconstitution assay, various other factors that determine the stem cell's repopulation ability can be discerned. These may directly or indirectly affect signaling in the mammary stem cell niche and may or may not be considered part of the niche.

First of all, MECs only give rise to a ductal tree when they are grafted to the mammary fat pad; when they are transplanted to other adipose tissues they yield only very limited outgrowth [77]. Thus, similar to the skin, signals from cells not in direct contact with the stem cell are important for the stem cell function. The contribution of different cell types within the fat pad, such as fibroblasts, adipocytes, endothelial, perivascular and immune cells, remains to be determined.

An additional level of complexity stems from the fact that the gland has to coordinate all its activities with systemic requirements conveyed, above all, by the female reproductive hormones estrogens, progesterone and prolactin. Indeed, MECs that are grafted 


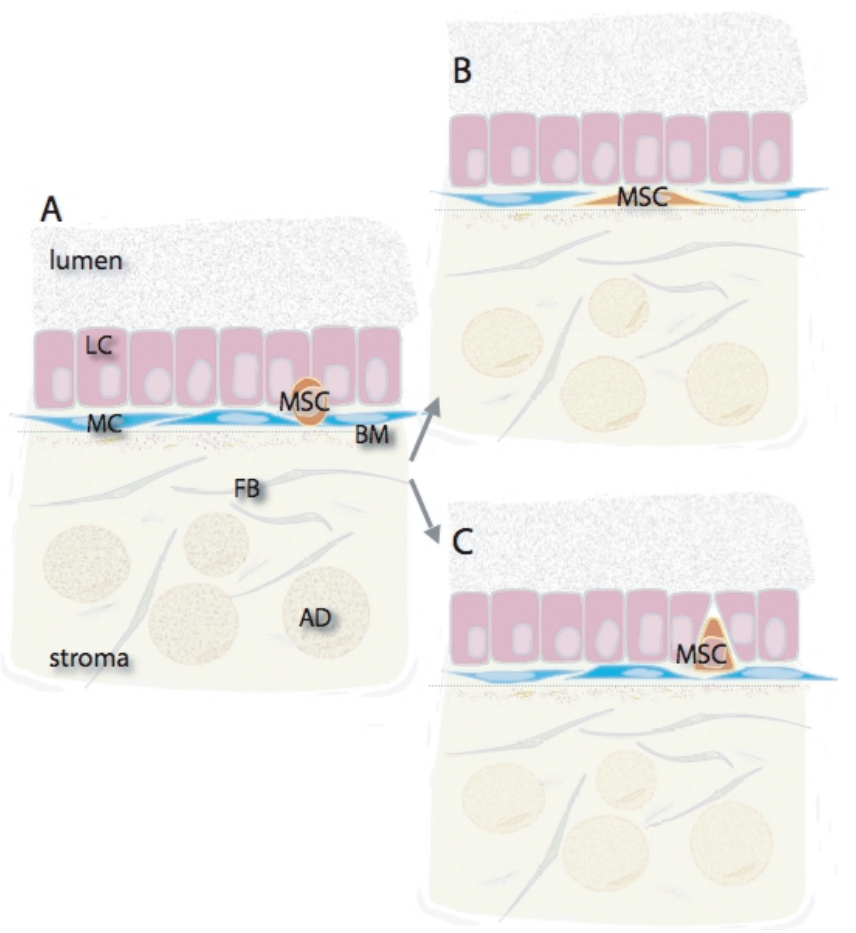

Fig. 5. Localization of the mammary gland stem cell. A: Schematic diagram illustrating the cellular composition of a milk duct in the mouse mammary gland: LC: luminal cell; MC: myoepithelial cell; MSC: mammary stem cell AD: adipocyte; FB: fibroblast. B: Localization of the mammary gland stem cells based on functional studies of different FACS sorted populations. The population enriched for cells of high reconstitution potential expresses myoepithelial markers. $C$ : localization of the mammary stem cells based on morphological characteristics. Small light cells (SLCs) localize in an intermediate position between myoepithelial and luminal layer and do not reach the lumen.

to a cleared fat pad will only grow out when estrogens are present; in ovariectomized females no ductal outgrowth occurs; local estrogen administration restores it [29]. The systemic hormonal milieu translates into local cues via the estrogen and progesterone receptors present on a subset of luminal epithelial cells, that we call the sensor cells [15]. These sensor cells are either part of the niche or near the niche, they may directly or indirectly signal to the stem cells. As the hormonal milieu changes, the niche and it's signaling also change.

\section{THE NICHE DURING PUBERTY}

The fat pad reconstitution assay reflects growth as it occurs physiologically during puberty. Pubertal ductal outgrowth is driven by ovarian estrogens [29,75] that act through ER $\alpha$ in the mammary epithelium [67], which is expressed in about $30 \%$ of the luminal epithelial cells at this stage [90,138]. When ER $\alpha^{-/-}$ MECs are grafted to cleared fat pads no outgrowth occurs; however, when ER $\alpha$ deficient cells are mingled with WT cells, they contribute extensively to the duc- tal outgrowth and give rise to both myoepithelial and luminal cells [67]. Thus, ER $\alpha$ deficient mammary epithelia contain stem cells; a finding that is consistent with the observation that the cell fraction enriched for stem cells is hormone receptor negative [4]. The ER negative stem cell can only unfold its potential when it is in vicinity of an $\operatorname{ER} \alpha$ positive cells that translate estrogen action into a paracrine signal. Whether the hormone receptor positive sensor cell is actually part of the niche and interacts directly with the stem cell or whether it may be a few cell diameters away from the stem cell remains unclear.

Which are the downstream mediators of estrogens? The EGFR ligands epidermal growth factor (EGF), transforming growth factor $\alpha$ (TGF $\alpha$ ), and amphiregulin administered locally, can restore ductal elongation in ovariectomized mice arguing that EGFR signaling is important downstream of $\operatorname{ER} \alpha[24,50,100]$. The physiologically relevant EGF family member is amphiregulin; its transcription is specifically and selectively induced by $17-\beta$-estradiol in the puberal mammary epithelium [23]. The membrane-bound protease TACE/ADAM17 cleaves and thereby activates 


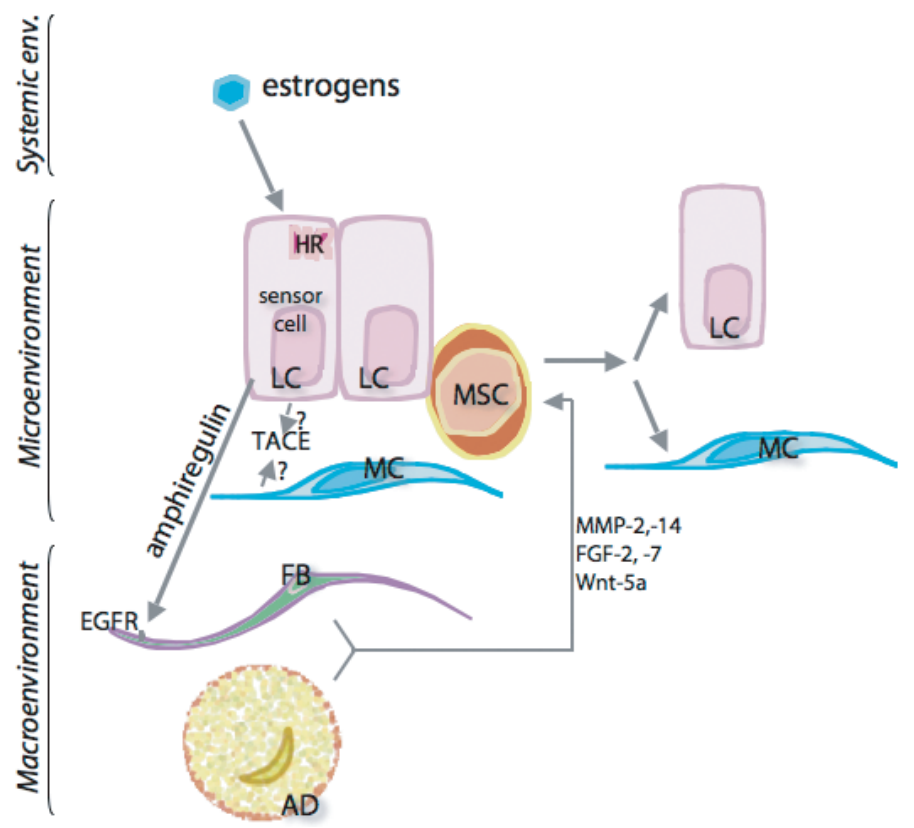

Fig. 6. Model of pubertal mammary stem cell niche: Estrogens from the systemic environment acting on ER $\alpha$ receptor positive sensor cell, induce expression of amphiregulin that is activated by TACE and acts via the EGFR on stromal cells. The basal membrane is disrupted in this phase of the development. In response to this stimulation, the stromal cells release factors like FGFs and MMPs that in turn impinge directly or indirectly on the stem cell to modulate its behavior. See text for further explanations. MSC: mammary stem cell; LC: luminal cell; MC: myoepithelial cell; FB: fibroblast, AD: adipocyte; HR: hormone receptor, here: ER $\alpha$.

amphiregulin [61,112]. Both amphiregulin and TACE are required in the mammary epithelium for ductal outgrowth [23,103]. In chimeric epithelia formed by amphiregulin ${ }^{-/-}$and WT cells, the mutant cells proliferate and contribute to cell both compartments consistent with amphiregulin acting as a paracrine mediator of estrogen action [23]. The mutant cells never give rise to an entire ductal segment but are always observed within a few cell diameters of WT cells [23] indicating that close interactions are required during ductal outgrowth to relegate the estrogen-induced signals to $\mathrm{ER} \alpha$ negative stem and/or progenitor cells.

In the absence of EGFR, the cognate receptor of amphiregulin, ductal outgrowth fails to occur. Tissue recombination studies revealed that EGFR deficient stroma abolishes the growth of a wild type epithelium whereas EGFR deficient epithelium grows in a WT fat pad [131] indicating that the prime target of amphiregulin are stromal cells, which may in turn release factors to stimulate either the niche or the stem cells (Fig. 6).

During estrogen-driven ductal outgrowth, epithelial cells at the tip of the growing ducts, are in direct contact with the stroma because the basal lamina is disrupted in this zone of active proliferation [88]. Thus, it is conceivable that stromal cells may be part of the niche (Fig. 6).
The nature of the stromal factors released in response to amphiregulin that talk back to the mammary epithelium remains to be elucidated as well as the cell type within the stroma that is responsible for secreting/activating these factors. Furthermore, it is unclear whether these stromal factors act directly on the stem cell or impinge on niche cells.

Candidate stromal factors are the matrix metalloproteinases (MMP) -14 and -2 [58], previously reported as EGFR targets which may activate membrane bound/ECM-sequestered growth factors and/or components of ECM such as collagens, laminin, fibronectin, proteoglycans, the TGF- $\beta$ inhibitor decorin, and FasL [101]. Other attractive contenders for the stromal mediators are the fibroblast growth factors (FGFs) -7 and -2 [102], they elicit ductal morphogenesis in a 3D matrigel assay [97] and stimulate growth and branching of $\mathrm{EGFR}^{-/-}$mammary organoids in culture [103]. Interestingly, FGF-2 (basic FGF) is a critical component in the medium for mammospheres [33, 35] suggesting that activation of FGF signaling is important to stem cells [33]. Whether these FGFs are induced in the stroma in response to amphiregulin and whether they act directly on the stem cell or indirectly via niche cells both in vivo and in mammospheres remains to be determined. 


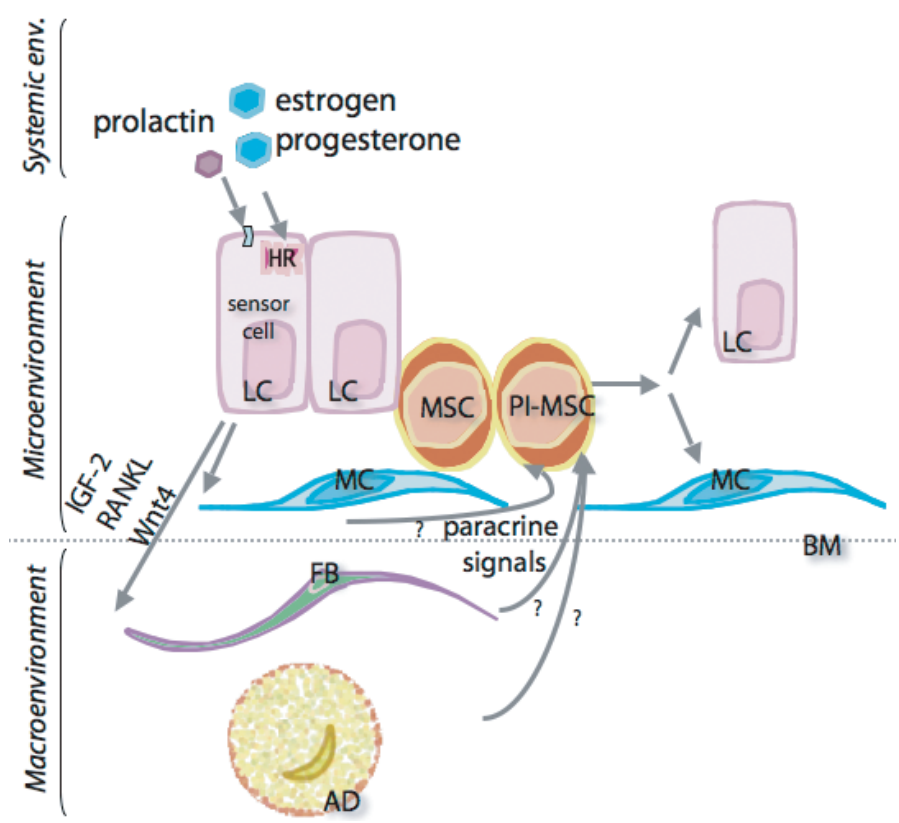

Fig. 7. Model of pregnancy-associated stem cell niche. Systemic progesterone and prolactin, in the presence of estrogens, act together in the development of the mammary gland during pregnancy. These hormones reach their receptors in luminal cells belonging to the stem cell microenvironment. In response, the sensor cells release several factors like IGF-2, Wnt 4 and RANKL. These influence the surrounding cells, and may directly or indirectly influence the stem cells and parity induced-stem cells. MSC: mammary stem cell; PI-MSC: parity identified-mammary stem cell; LC: luminal cell; MC: myoepithelial cell; FB: fibroblast; AD: adipocyte; HR: hormone receptor; BM: basal membrane.

It is also possible that default inhibitory influences exerted on the niche are relieved by a stroma-derived factor. TGF- $\beta$ acts as a key negative regulator of proliferation on many epithelial cell types including MECs [28,36]. Intriguingly, decorin is a TGF- $\beta$ inhibitor highly expressed in mammospheres [33] and could be secreted by stromal cells in response to EGFR stimulation.

TGF- $\beta$ regulates the expression of Wnt-5a [89], a Wnt that activates non canonical wnt signaling [52,60, 122,130] and can inhibit canonical wnt signaling [71, $119,129]$. Wnt-5a mediates a subset of TGF- $\beta$ inhibitory actions and in Wnt-5a-/- mammary epithelia the highly proliferative ductal tips, terminal endbuds (TEBs) are enlarged [89] suggesting that down modulation of TGF- $\beta / \mathrm{Wnt}-5$ a signaling and, by extension up regulation of canonical wnt signaling, may indeed promote activation of stem cells. However, it is difficult to reconcile these functional data with the observation that expression of Wnt-5a mRNA is enriched in the TEBs compared to subtending ducts [58] when TGF $\beta$ activity and hence Wnt-5a expression should be down modulated at the active growth front.

In the mammary gland, as in the hematopoietic system and in the epidermis, Wnt signaling may be important in determining the stem cell compartment. Mice that ectopically express Wnt-1 in the mammary epithelium have an increase in the CD29 high $\mathrm{CD} 49^{\text {high }}$ compartment [96] and tumors arising in the mammary glands of these mice express progenitor markers [63]. Moreover, microRNAs, which have been shown to be enriched in stem cell populations, are increased when Wnt-1 is overexpressed in MECs [43]. Whether wnt signaling is required in the stem cell itself, in niche cells, or exerts more indirect effects remains to be addressed.

Expression of Notch-3, SCF and the Wnt receptor Frizzled 2 has been found increased when expression profiles of mammospheres and of cells grown on adherent plates were compared [33] suggesting that Notch, Wnt and Kit signaling all of which are important in the hematopoietic niche may also have a role in the mammary gland niche. Consistent with such a scenario, inhibition of Notch signaling interferes with growth of mammospheres [34]. In vivo data, however, suggest that regulation of Notch signaling is complex and cell type dependent. Both ectopic activation $[47,98]$ as well as loss of function [91] can interfere with ductal outgrowth arguing that the timing and the level of expression as well as the targeted cell type will need to be considered. BMP signaling function has not been addressed in the mammary gland. 


\section{STEM CELL NICHE DURING PREGNANCY}

Once the ducts reach the edges of the fat pad, they cease to grow; this usually coincides with the onset of sexual maturity. With recurrent estrous cycles the complexity of the ductal system increases through lateral branching driven by cyclic increases in serum progesterone levels [88]. During early pregnancy, progesterone levels increase and sidebranching is further enhanced; later, prolactin drives alveologenesis. It is not clear to what extent this proliferation requires stem cell activity or merely reflects an expansion of transient amplifying cells.

During pregnancy a novel stem cell population becomes apparent, the parity-identified stem cells, (PISCs). These cells were tracked using double transgenic mice, which express Cre driven by the milk protein, whey acidic protein (WAP) promoter and a LacZ gene that is preceded by a floxed stop codon (WAPCre/Rosa26-flox-stop-flox-lacZ). In these double transgenic mice, MECs that differentiate and hence express WAP will induce Cre recombinase resulting in the excision of the stop codon in front of the LacZ gene and expression of $\beta$-galactosidase. Subsequently, the cells express the enzyme constitutively and can readily be visualized by a simple X-gal staining [124]. Contrary to the widely held belief that differentiated cells are lost during involution, these cells that have expressed WAP remain all over the ductal system after post-lactational remodeling. When epithelium from parous double transgenic mice is transplanted to cleared mammary fat pad, LacZ positive cells contribute substantially to the outgrowth and are found in all cellular compartments [124], moreover, they are present in the $\mathrm{CD} 24^{+} / \mathrm{CD} 49 \mathrm{f}^{\text {high }}$ population [69]. Interestingly, when PI-SCs are grafted on their own, as achieved by injecting them into cleared fat pads in limiting dilutions, they do not give rise to complete ductal outgrowths but form lobules indicating that their intrinsic potential is more restricted than that of the common mammary SCs $[12,124,125]$.

A few PI-SCs develop during estrous [10] but the bulk of PI-SCs is induced during pregnancy [124]. This points to the existence of a pregnancy-specific stem cell niche. Intriguingly, the pregnancy stem cell niche can induce adult testicular cells into milk-producing MECs [11]. The male germ cells are capable of selfrenewal upon transplantation and contribute to both luminal and myoepithelial cell lineages in the reconstituted glands [11].
What distinguishes the pregnancy niche from the niche in the virgin female? During pregnancy the same cell types will be interacting with stem cells as in the virgin animal (Figs 6 and 7). In contrast to the "pubertal niche" the basal membrane remains intact during pregnancy suggesting that interactions with the stroma may be less extensive at this stage. At this stage, the myoepithelial layer is less continuous probably allowing luminal cells to contact the basal membrane [88].

Progesterone and prolactin act in the presence of estrogens, that are required for progesterone receptor (PR) expression, to induce side branching and alveologenesis [17,18] (for review see [13]) by acting on their respective sensor cells. As a result local signals are induced that may directly impinge on stem cells or act on neighboring luminal or myoepithelial cells, possibly stromal cells that are part of the niche (Fig. 6).

Receptor Activator for Nuclear Factor $\kappa \mathrm{B}$ Ligand (RANKL) [14,74], Wnt-4 [16], calcitonin [44] and insulin like growth factor-2 (IGF-2) [14] (Fig. 7) have been implicated downstream of the pregnancy hormones. We speculate that Wnt-4 mobilizes stem cells either acting on them directly or indirectly through activation of niche cells. The offspring is induced to proliferate by RANKL. The functional importance of calcitonin induction by progesterone in this context is unclear. IGF-2 is an important factor for maintaining human embryonic stem cells in culture [8]; whether its role in alveologenesis in the mammary gland is linked to effects on stem cells remains to be tested.

A better understanding of PI-SCs and their niche is very important in light of the observation that early pregnancies have a protective effect against cancer. This is evident from epidemiologic studies on humans [40] and can be reproduced in rodents $[19,38]$. Indeed, Wagner and Smith argue that the specific properties of the PI-SC population that set them apart from MSCs may underly the protective effect of pregnancy.

\section{CONCLUSIONS}

Thinking about stem cells and their niches has been largely influenced by the pioneering work performed in the readily accessible hematopoietic system. In the mammary gland, in addition to the immediate microenvironment, various stromal components and above all the systemic hormonal milieu are crucial control elements of stem cell function. The female reproductive hormones acting through sensor cells within the luminal epithelium, trigger a cascade of paracrine signal- 
ing events that impinge on stem cells and their niches. Some signaling pathways have been implicated that appear to be of general importance to stem cells and their niches such as Wnt, Notch, BMP signaling. In the mammary gland, their exact role remains to be established. In addition a number of pathways with organspecific functions, such as amphiregulin in the mammary niche versus osteopontin in the hematopoeitic niche have been identified.

The challenge is to reconcile morphological hallmarks of stem cells in situ and FACS phenotyping ex vivo so that the stem cells and their niches can eventually be defined and characterized in vivo. We need to integrate the models about stemness and differentiation as in the hematopoietic system where cells are single and live in suspension, with the complex 3D structure of the mammary gland that changes substantially during development, as well as the mesenchymal interactions that influence it.

A better understanding of the mammary niche and its dependence on developmental stage and hormonal milieu will provide novel insights into how breast cancer arises.

\section{ACKNOWLEDGEMENTS}

We thank Anne Wilson for helpful comments and özden Yalcin and Renuga Devi Rajaram for carefully reading the manuscript. Tamara Tanos was supported by Oncosuisse (KFP OCS-02065).

\section{REFERENCES}

[1] F. Arai, A. Hirao, M. Ohmura, H. Sato, S. Matsuoka, K Takubo, K. Ito, G.Y. Koh and T. Suda, Tie2/angiopoietin-1 signaling regulates hematopoietic stem cell quiescence in the bone marrow niche, Cell 118 (2004), 149-161.

[2] I. Arnold and F.M. Watt, c-Myc activation in transgenic mouse epidermis results in mobilization of stem cells and differentiation of their progeny, Curr Biol 11 (2001), 558568.

[3] N. Askenasy, T. Zorina, D.L. Farkas and I. Shalit, Transplanted hematopoietic cells seed in clusters in recipient bone marrow in vivo, Stem Cells 20 (2002), 301-310.

[4] M.L. Asselin-Labat, M. Shackleton, J. Stingl, F. Vaillant, N.C. Forrest, C.J. Eaves, J.E. Visvader and G.J. Lindeman, Steroid hormone receptor status of mouse mammary stem cells, J Natl Cancer Inst 98 (2006), 1011-1014.

[5] E. Baena, M. Ortiz, A.C. Martinez and I.M. de Alboran, cMyc is essential for hematopoietic stem cell differentiation and regulates Lin(-)Sca-1(+)c-Kit(-) cell generation through p21, Exp Hematol 35 (2007), 1333-1343.
[6] N. Barker, J.H. van Es, J. Kuipers, P. Kujala, M. van den Born, M. Cozijnsen, A. Haegebarth, J. Korving, H. Begthel, P.J. Peters and H. Clevers, Identification of stem cells in small intestine and colon by marker gene Lgr5, Nature 449 (2007), 1003-1007.

[7] A.J. Becker, C.E. Mc and J.E. Till, Cytological demonstration of the clonal nature of spleen colonies derived from transplanted mouse marrow cells, Nature 197 (1963), 452-454.

[8] S.C. Bendall, M.H. Stewart, P. Menendez, D. George, K. Vijayaragavan, T. Werbowetski-Ogilvie, V. Ramos-Mejia, A. Rouleau, J. Yang, M. Bosse, G. Lajoie and M. Bhatia, IGF and FGF cooperatively establish the regulatory stem cell niche of pluripotent human cells in vitro, Nature 448 (2007), 1015-1021.

[9] C. Blanpain and E. Fuchs, Epidermal stem cells of the skin, Annu Rev Cell Dev Biol 22 (2006), 339-373.

[10] B.W. Booth, C.A. Boulanger and G.H. Smith, Alveolar progenitor cells develop in mouse mammary glands independent of pregnancy and lactation, J Cell Physiol 212 (2007), 729-736.

[11] C.A. Boulanger, D.L. Mack, B.W. Booth and G.H. Smith, Interaction with the mammary microenvironment redirects spermatogenic cell fate in vivo, Proc Natl Acad Sci USA 104 (2007), 3871-3876.

[12] C.A. Boulanger, K.U. Wagner and G.H. Smith, Parityinduced mouse mammary epithelial cells are pluripotent, self-renewing and sensitive to TGF-betal expression, Oncogene 24 (2005), 552-560.

[13] C. Brisken, Hormonal control of alveolar development and its implications for breast carcinogenesis, J Mammary Gland Biol Neoplasia 7 (2002), 39-48.

[14] C. Brisken, A. Ayyannan, C. Nguyen, A. Heineman, F. Reinhardt, J. Tan, S.K. Dey, G.P. Dotto and R.A. Weinberg, IGF2 is a mediator of prolactin-induced morphogenesis in the breast, Dev Cell 3 (2002), 877-887.

[15] C. Brisken and S. Duss, Stem cells and the stem cell niche in the breast: an integrated hormonal and developmental perspective, Stem Cell Rev 3 (2007), 147-156.

[16] C. Brisken, A. Heineman, T. Chavarria, B. Elenbaas, J. Tan, S.K. Dey, J.A. McMahon, A.P. McMahon and R.A. Weinberg, Essential function of Wnt-4 in mammary gland development downstream of progesterone signaling, Genes Dev 14 (2000), 650-654.

[17] C. Brisken, S. Kaur, T.E. Chavarria, N. Binart, R.L. Sutherland, R.A. Weinberg, P.A. Kelly and C.J. Ormandy, Prolactin controls mammary gland development via direct and indirect mechanisms, Dev Biol 210 (1999), 96-106.

[18] C. Brisken, S. Park, T. Vass, J.P. Lydon, B.W. O’Malley and R.A. Weinberg, A paracrine role for the epithelial progesterone receptor in mammary gland development, Proc Natl Acad Sci USA 95 (1998), 5076-5081.

[19] K. Britt, A. Ashworth and M. Smalley, Pregnancy and the risk of breast cancer, Endocr Relat Cancer 14 (2007), 907-933.

[20] L.M. Calvi, G.B. Adams, K.W. Weibrecht, J.M. Weber, D.P. Olson, M.C. Knight, R.P. Martin, E. Schipani, P. Divieti, F.R. Bringhurst, L.A. Milner, H.M. Kronenberg and D.T. Scadden, Osteoblastic cells regulate the haematopoietic stem cell niche, Nature 425 (2003), 841-846.

[21] E. Candi, A. Rufini, A. Terrinoni, A. Giamboi-Miraglia, A.M. Lena, R. Mantovani, R. Knight and G. Melino, DeltaNp63 regulates thymic development through enhanced expression of FgfR2 and Jag2, Proc Natl Acad Sci USA 104 (2007), 11999-2004. 
[22] G. Chepko and G.H. Smith, Three division-competent, structurally-distinct cell populations contribute to murine mammary epithelial renewal, Tissue Cell 29 (1997), 239_ 253.

[23] L. Ciarloni, S. Mallepelland C. Brisken, Amphiregulin is an essential mediator of estrogen receptor alpha function in mammary gland development, Proc Natl Acad Sci USA 104 (2007), 5455-5460.

[24] S. Coleman, G.B. Silberstein and C.W. Daniel, Ductal morphogenesis in the mouse mammary gland: evidence supporting a role for epidermal growth factor, Dev Biol 127 (1988), 304-315.

[25] G. Cotsarelis, T.T. Sun and R.M. Lavker, Label-retaining cells reside in the bulge area of pilosebaceous unit: implications for follicular stem cells, hair cycle, and skin carcinogenesis, Cell 61 (1990), 1329-1337.

[26] S.L. Crittenden, D.S. Bernstein, J.L. Bachorik, B.E. Thompson, M. Gallegos, A.G. Petcherski, G. Moulder, R. Barstead, M. Wickens and J. Kimble, A conserved RNA-binding protein controls germline stem cells in Caenorhabditis elegans, Nature 417 (2002), 660-663.

[27] C.W. Daniel, K.B. De Ome, J.T. Young, P.B. Blair and L.J. Faulkin, Jr., The in vivo life span of normal and preneoplastic mouse mammary glands: a serial transplantation study, Proc Natl Acad Sci USA 61 (1968), 53-60.

[28] C.W. Daniel, S. Robinson and G.B. Silberstein, The role of TGF-beta in patterning and growth of the mammary ductal tree, J Mammary Gland Biol Neoplasia 1 (1996), 331-341.

[29] C.W. Daniel, G.B. Silberstein and P. Strickland, Direct action of 17 beta-estradiol on mouse mammary ducts analyzed by sustained release implants and steroid autoradiography, Cancer Res 47 (1987), 6052-6057.

[30] C.W. Daniel and L.J. Young, Influence of cell division on an aging process. Life span of mouse mammary epithelium during serial propagation in vivo, Exp Cell Res 65 (1971), 27-32.

[31] R. DasGupta and E. Fuchs, Multiple roles for activated LEF/TCF transcription complexes during hair follicle development and differentiation, Development 126 (1999), 45574568.

[32] K.B. Deome, L.J. Faulkin, Jr., H.A. Bern and P.B. Blair, Development of mammary tumors from hyperplastic alveolar nodules transplanted into gland-free mammary fat pads of female C3H mice, Cancer Res 19 (1959), 515-520.

[33] G. Dontu, W.M. Abdallah, J.M. Foley, K.W. Jackson, M.F. Clarke, M.J. Kawamura and M.S. Wicha, In vitro propagation and transcriptional profiling of human mammary stem/progenitor cells, Genes Dev 17 (2003), 1253-1270.

[34] G. Dontu, K.W. Jackson, E. McNicholas, M.J. Kawamura, W.M. Abdallah and M.S. Wicha, Role of Notch signaling in cell-fate determination of human mammary stem/progenitor cells, Breast Cancer Res 6 (2004), R605-615.

[35] G. Dontu and M.S. Wicha, Survival of mammary stem cells in suspension culture: implications for stem cell biology and neoplasia, J Mammary Gland Biol Neoplasia 10 (2005), 75-86.

[36] K.B. Ewan, G. Shyamala, S.A. Ravani, Y. Tang, R. Akhurst, L. Wakefield and M.H. Barcellos-Hoff, Latent transforming growth factor-beta activation in mammary gland: regulation by ovarian hormones affects ductal and alveolar proliferation, Am J Pathol 160 (2002), 2081-2093.

[37] E. Fuchs, T. Tumbar and G. Guasch, Socializing with the neighbors: stem cells and their niche, Cell 116 (2004), 769778 .
[38] M.R. Ginger and J.M. Rosen, Pregnancy-induced changes in cell-fate in the mammary gland, Breast Cancer Res 5 (2003), 192-197.

[39] T. Gudjonsson, R. Villadsen, H.L. Nielsen, L. RonnovJessen, M.J. Bissell and O.W. Petersen, Isolation, immortalization, and characterization of a human breast epithelial cell line with stem cell properties, Genes Dev 16 (2002), 693-706.

[40] R.V. Harrison, N.K. Janz, R.A. Wolfe, P.J. Tedeschi, X. Huang and L.F. McMahon, Jr., 5-Year mammography rates and associated factors for older women, Cancer 97 (2003), 1147-1155.

[41] L. Hennighausen and G.W. Robinson, Information networks in the mammary gland, Nat Rev Mol Cell Biol 6 (2005), $715-725$.

[42] J. Huelsken, R. Vogel, B. Erdmann, G. Cotsarelis and W. Birchmeier, beta-Catenin controls hair follicle morphogenesis and stem cell differentiation in the skin, Cell 105 (2001), 533-545.

[43] I. Ibarra, Y. Erlich, S.K. Muthuswamy, R. Sachidanandam and G.J. Hannon, A role for microRNAs in maintenance of mouse mammary epithelial progenitor cells, Genes Dev 21 (2007), 3238-3243.

[44] P.M. Ismail, F.J. DeMayo, P. Amato and J.P. Lydon, Progesterone induction of calcitonin expression in the murine mammary gland, J Endocrinol 180 (2004), 287-295.

[45] M. Ito, K. Kizawa, M. Toyoda and M. Morohashi, Labelretaining cells in the bulge region are directed to cell death after plucking, followed by healing from the surviving hair germ, J Invest Dermatol 119 (2002), 1310-1316.

[46] M. Ito, Y. Liu, Z. Yang, J. Nguyen, F. Liang, R.J. Morris and G. Cotsarelis, Stem cells in the hair follicle bulge contribute to wound repair but not to homeostasis of the epidermis, Nat Med 11 (2005), 1351-1354.

[47] C. Jhappan, D. Gallahan, C. Stahle, E. Chu, G.H. Smith, G. Merlino and R. Callahan, Expression of an activated Notchrelated int-3 transgene interferes with cell differentiation and induces neoplastic transformation in mammary and salivary glands, Genes Dev 6 (1992), 345-355.

[48] P.H. Jones, S. Harper and F.M. Watt, Stem cell patterning and fate in human epidermis, Cell 80 (1995), 83-93.

[49] F.N. Karanu, B. Murdoch, L. Gallacher, D.M. Wu, M. Koremoto, S. Sakano and M. Bhatia, The notch ligand jagged1 represents a novel growth factor of human hematopoietic stem cells, J Exp Med 192 (2000), 1365-1372.

[50] N.J. Kenney, G.H. Smith, K. Rosenberg, M.L. Cutler and R.B. Dickson, Induction of ductal morphogenesis and lobular hyperplasia by amphiregulin in the mouse mammary gland, Cell Growth Differ 7 (1996), 1769-1781.

[51] A.A. Kiger, H. White-Cooper and M.T. Fuller, Somatic support cells restrict germline stem cell self-renewal and promote differentiation, Nature 407 (2000), 750-754.

[52] A. Kikuchi, S. Kishida and H. Yamamoto, Regulation of Wnt signaling by protein-protein interaction and posttranslational modifications, Exp Mol Med 38 (2006), 1-10.

[53] P. Kirstetter, K. Anderson, B.T. Porse, S.E. Jacobsen and C. Nerlov, Activation of the canonical Wnt pathway leads to loss of hematopoietic stem cell repopulation and multilineage differentiation block, Nat Immunol 7 (2006), 1048-1056.

[54] H.G. Kopp, S.T. Avecilla, A.T. Hooper and S. Rafii, The bone marrow vascular niche: home of HSC differentiation and mobilization, Physiology (Bethesda) 20 (2005), 349-356.

[55] H.I. Kornblum, Introduction to neural stem cells, Stroke 38 (2007), 810-816. 
[56] M.I. Koster, D. Dai, B. Marinari, Y. Sano, A. Costanzo, M. Karin and D.R. Roop, p63 induces key target genes required for epidermal morphogenesis, Proc Natl Acad Sci USA 104 (2007), 3255-3260.

[57] M.I. Koster, D. Dai and D.R. Roop, Conflicting roles for p63 in skin development and carcinogenesis, Cell Cycle 6 (2007), 269-273.

[58] H. Kouros-Mehr and Z. Werb, Candidate regulators of mammary branching morphogenesis identified by genome-wide transcript analysis, Dev Dyn 235 (2006), 3404-3412.

[59] Y. Kubota, K. Takubo and T. Suda, Bone marrow long label-retaining cells reside in the sinusoidal hypoxic niche, Biochem Biophys Res Commun 366 (2008), 335-339.

[60] M. Kuhl, L.C. Sheldahl, M. Park, J.R. Miller and R.T. Moon, The Wnt/Ca2 + pathway: a new vertebrate Wnt signaling pathway takes shape, Trends Genet 16 (2000), 279-283.

[61] D.C. Lee, S.W. Sunnarborg, C.L. Hinkle, T.J. Myers, M.Y. Stevenson, W.E. Russell, B.J. Castner, M.J. Gerhart, R.J. Paxton, R.A. Black, A. Chang and L.F. Jackson, TACE/ADAM17 processing of EGFR ligands indicates a role as a physiological convertase, Ann N Y Acad Sci 995 (2003), 22-38.

[62] L. Li and T. Xie, Stem cell niche: structure and function, Annu Rev Cell Dev Biol 21 (2005), 605-631.

[63] Y. Li, B. Welm, K. Podsypanina, S. Huang, M. Chamorro, X. Zhang, T. Rowlands, M. Egeblad, P. Cowin, Z. Werb, L.K. Tan, J.M. Rosen and H.E. Varmus, Evidence that transgenes encoding components of the Wnt signaling pathway preferentially induce mammary cancers from progenitor cells, Proc Natl Acad Sci USA 100 (2003), 15853-15858.

[64] C. Lo Celso, D.M. Prowse and F.M. Watt, Transient activation of beta-catenin signalling in adult mouse epidermis is sufficient to induce new hair follicles but continuous activation is required to maintain hair follicle tumours, Development 131 (2004), 1787-1799.

[65] S. Lyle, M. Christofidou-Solomidou, Y. Liu, D.E. Elder, S. Albelda and G. Cotsarelis, The C8/144B monoclonal antibody recognizes cytokeratin 15 and defines the location of human hair follicle stem cells, J Cell Sci 111(Pt 21) (1998), 3179-3188.

[66] S.D. Lyman and S.E. Jacobsen, c-kit ligand and Flt3 ligand: stem/progenitor cell factors with overlapping yet distinct activities, Blood 91 (1998), 1101-1134.

[67] S. Mallepell, A. Krust, P. Chambon and C. Brisken, Paracrine signaling through the epithelial estrogen receptor alpha is required for proliferation and morphogenesis in the mammary gland, Proc Natl Acad Sci USA 103 (2006), 2196-2201.

[68] S.J. Mancini, N. Mantei, A. Dumortier, U. Suter, H.R. MacDonald and F. Radtke, Jagged1-dependent Notch signaling is dispensable for hematopoietic stem cell self-renewal and differentiation, Blood 105 (2005), 2340-2342.

[69] L.A. Matulka, A.A. Triplett and K.U. Wagner, Parity-induced mammary epithelial cells are multipotent and express cell surface markers associated with stem cells, Dev Biol $\mathbf{3 0 3}$ (2007), 29-44.

[70] C.A. Micchelli and N. Perrimon, Evidence that stem cells reside in the adult Drosophila midgut epithelium, Nature 439 (2006), 475-479.

[71] A.J. Mikels and R. Nusse, Purified Wnt5a protein activates or inhibits beta-catenin-TCF signaling depending on receptor context, PLoS Biol 4 (2006), e115.

[72] A.A. Mills, B. Zheng, X.J. Wang, H. Vogel, D.R. Roop and A. Bradley, p63 is a p53 homologue required for limb and epidermal morphogenesis, Nature 398 (1999), 708-713.
[73] R.C. Moraes, X. Zhang, N. Harrington, J.Y. Fung, M.F. Wu, S.G. Hilsenbeck, D.C. Allred and M.T. Lewis, Constitutive activation of smoothened (SMO) in mammary glands of transgenic mice leads to increased proliferation, altered differentiation and ductal dysplasia, Development 134 (2007), 1231-1242.

[74] B. Mulac-Jericevic, J.P. Lydon, F.J. DeMayo and O.M. Conneely, Defective mammary gland morphogenesis in mice lacking the progesterone receptor B isoform, Proc Natl Acad Sci USA 100 (2003) 9744-9949.

[75] S. Nandi, Endocrine control of mammarygland development and function in the $\mathrm{C} 3 \mathrm{H} / \mathrm{He} \mathrm{Crgl}$ mouse, J Natl Cancer Inst 21 (1958), 1039-1063.

[76] M.J. Nemeth, L. Topol, S.M. Anderson, Y. Yang, and D.M. Bodine, Wnt5a inhibits canonical Wnt signaling in hematopoietic stem cells and enhances repopulation, Proc Natl Acad Sci USA 104 (2007), 15436-15441.

[77] M.C. Neville, D. Medina, J. Monks and R.C. Hovey, The mammary fat pad, J Mammary Gland Biol Neoplasia 3 (1998), 109-116.

[78] B.C. Nguyen, K. Lefort, A. Mandinova, D. Antonini, V. Devgan, G. Della Gatta, M.I. Koster, Z. Zhang, J. Wang, A. Tommasi di Vignano, J. Kitajewski, G. Chiorino, D.R. Roop, C. Missero and G.P. Dotto, Cross-regulation between Notch and $\mathrm{p} 63$ in keratinocyte commitment to differentiation, Genes Dev 20 (2006), 1028-1042.

[79] S.K. Nilsson, H.M. Johnston and J.A. Coverdale, Spatial localization of transplanted hemopoietic stem cells: inferences for the localization of stem cell niches, Blood 97 (2001), 2293-2299.

[80] S.K. Nilsson, H.M. Johnston, G.A. Whitty, B. Williams, R.J. Webb, D.T. Denhardt, I. Bertoncello, L.J. Bendall, P.J. Simmons and D.N. Haylock, Osteopontin, a key component of the hematopoietic stem cell niche and regulator of primitive hematopoietic progenitor cells, Blood 106 (2005), 12321239

[81] E.J. Ormerod and P.S. Rudland, Regeneration of mammary glands in vivo from isolated mammary ducts, J Embryol Exp Morphol 96 (1986), 229-243.

[82] H. Oshima, A. Rochat, C. Kedzia, K. Kobayashi and Y. Barrandon, Morphogenesis and renewal of hair follicles from adult multipotent stem cells, Cell 104 (2001), 233-245.

[83] C. Pechoux, T. Gudjonsson, L. Ronnov-Jessen, M.J. Bissell and O.W. Petersen, Human mammary luminal epithelial cells contain progenitors to myoepithelial cells, Dev Biol 206 (1999), 88-99.

[84] M.V. Plikus, J.A. Mayer, D. de la Cruz, R.E. Baker, P.K. Maini, R. Maxson and C.M. Chuong, Cyclic dermal BMP signalling regulates stem cell activation during hair regeneration, Nature 451 (2008), 340-344.

[85] F. Radtke, A. Wilson, S.J. Mancini and H.R. MacDonald, Notch regulation of lymphocyte development and function, Nat Immunol 5 (2004), 247-253.

[86] A. Rangarajan, C. Talora, R. Okuyama, M. Nicolas, C. Mammucari, H. Oh, J.C. Aster, S. Krishna, D. Metzger, P. Chambon, L. Miele, M. Aguet, F. Radtke and G.P. Dotto, Notch signaling is a direct determinant of keratinocyte growth arrest and entry into differentiation, Embo J 20 (2001), 3427-3436.

[87] T. Reya, A.W. Duncan, L. Ailles, J. Domen, D.C. Scherer, K. Willert, L. Hintz, R. Nusse and I.L. Weissman, A role for Wnt signalling in self-renewal of haematopoietic stem cells, Nature 423 (2003), 409-414. 
[88] M.M. Richert, K.L. Schwertfeger, J.W. Ryder and S.M. Anderson, An atlas of mouse mammary gland development, $J$ Mammary Gland Biol Neoplasia 5 (2000), 227-241.

[89] K. Roarty and R. Serra, Wnt5a is required for proper mammary gland development and TGF-beta-mediated inhibition of ductal growth, Development 134 (2007), 3929-3939.

[90] J. Russo, X. Ao, C. Grill and I.H. Russo, Pattern of distribution of cells positive for estrogen receptor alpha and progesterone receptor in relation to proliferating cells in the mammary gland, Breast Cancer Res Treat 53 (1999), 217-227.

[91] P. Sansone, G. Storci, C. Giovannini, S. Pandolfi, S. Pianetti, M. Taffurelli, D. Santini, C. Ceccarelli, P. Chieco and M. Bonafe, p66Shc/Notch-3 interplay controls self-renewal and hypoxia survival in human stem/progenitor cells of the mammary gland expanded in vitro as mammospheres, Stem Cells 25 (2007), 807-815.

[92] M. Scheller, J. Huelsken, F. Rosenbauer, M.M. Taketo, W. Birchmeier, D.G. Tenen and A. Leutz, Hematopoietic stem cell and multilineage defects generated by constitutive betacatenin activation, Nat Immunol 7 (2006), 1037-1047.

[93] S. Schenk and V. Quaranta, Tales from the crypt[ic] sites of the extracellular matrix, Trends Cell Biol 13 (2003), 366-375.

[94] R. Schofield, The relationship between the spleen colonyforming cell and the haemopoietic stem cell, Blood Cells 4 (1978), 7-25.

[95] M. Senoo, F. Pinto, C.P. Crum and F. McKeon, p63 Is essential for the proliferative potential of stem cells in stratified epithelia, Cell 129 (2007), 523-536.

[96] M. Shackleton, F. Vaillant, K.J. Simpson, J. Stingl, G.K. Smyth, M.L. Asselin-Labat, L. Wu, G.J. Lindeman and J.E. Visvader, Generation of a functional mammary gland from a single stem cell, Nature 439 (2006), 84-88.

[97] M. Simian, Y. Hirai, M. Navre, Z. Werb, A. Lochter and M.J. Bissell, The interplay of matrix metalloproteinases, morphogens and growth factors is necessary for branching of mammary epithelial cells, Development 128 (2001), 3117 3131.

[98] G.H. Smith, D. Gallahan, F. Diella, C. Jhappan, G. Merlino and R. Callahan, Constitutive expression of a truncated INT3 gene in mouse mammary epithelium impairs differentiation and functional development, Cell Growth Differ 6 (1995), 563-577.

[99] G.H. Smith and D. Medina, A morphologically distinct candidate for an epithelial stem cell in mouse mammary gland, J Cell Sci 90(Pt 1) (1988), 173-183.

[100] S.M. Snedeker, C.F. Brown and R.P. DiAugustine, Expression and functional properties of transforming growth factor alpha and epidermal growth factor during mouse mammary gland ductal morphogenesis, Proc Natl Acad Sci USA $\mathbf{8 8}$ (1991), 276-280.

[101] I. Stamenkovic, Extracellular matrix remodelling: the role of matrix metalloproteinases, J Pathol 200 (2003), 448-464.

[102] M.D. Sternlicht, Key stages in mammary gland development: the cues that regulate ductal branching morphogenesis, Breast Cancer Res 8 (2006), 201.

[103] M.D. Sternlicht, S.W. Sunnarborg, H. Kouros-Mehr, Y. Yu, D.C. Lee and Z. Werb, Mammary ductal morphogenesis requires paracrine activation of stromal EGFR via ADAM17dependent shedding of epithelial amphiregulin, Development 132 (2005), 3923-3933.

[104] S. Stier, T. Cheng, D. Dombkowski, N. Carlesso and D.T. Scadden, Notch1 activation increases hematopoietic stem cell self-renewal in vivo and favors lymphoid over myeloid lineage outcome, Blood 99 (2002), 2369-2378.
[105] S. Stier, Y. Ko, R. Forkert, C. Lutz, T. Neuhaus, E. Grunewald, T. Cheng, D. Dombkowski, L.M. Calvi, S.R. Rittling and D.T. Scadden, Osteopontin is a hematopoietic stem cell niche component that negatively regulates stem cell pool size, J Exp Med 201 (2005), 1781-1791.

[106] J. Stingl, C.J. Eaves, U. Kuusk and J.T. Emerman, Phenotypic and functional characterization in vitro of a multipotent epithelial cell present in the normal adult human breast, Differentiation 63 (1998), 201-213.

[107] J. Stingl, C.J. Eaves, I. Zandieh and J.T. Emerman, Characterization of bipotent mammary epithelial progenitor cells in normal adult human breast tissue, Breast Cancer Res Treat 67 (2001), 93-109.

[108] J. Stingl, P. Eirew, I. Ricketson, M. Shackleton, F. Vaillant, D. Choi, H.I. Li and C.J. Eaves, Purification and unique properties of mammary epithelial stem cells, Nature 439 (2006), 993-997.

[109] T. Suda and F. Arai, Wnt signaling in the niche, Cell 132 (2008), 729-730.

[110] T. Sugiyama, H. Kohara, M. Noda and T. Nagasawa, Maintenance of the hematopoietic stem cell pool by CXCL12CXCR4 chemokine signaling in bone marrow stromal cell niches, Immunity 25 (2006), 977-988.

[111] X. Sun, X. Fu and Z. Sheng, Cutaneous stem cells: something new and something borrowed, Wound Repair Regen 15 (2007), 775-785

[112] S.W. Sunnarborg, C.L. Hinkle, M. Stevenson, W.E. Russell, C.S. Raska, J.J. Peschon, B.J. Castner, M.J. Gerhart, R.J. Paxton, R.A. Black and D.C. Lee, Tumor necrosis factoralpha converting enzyme (TACE) regulates epidermal growth factor receptor ligand availability, J Biol Chem 277 (2002), 12838-12845.

[113] M. Tavassoli, Structure and function of sinusoidal endothelium of bone marrow, Prog Clin Biol Res 59B (1981), 249256.

[114] M. Tavassoli, Hemopoietic endothelium, incognito, Exp Hematol 20 (1992), 386-387.

[115] G. Taylor, M.S. Lehrer, P.J. Jensen, T.T. Sun and R.M. Lavker, Involvement of follicular stem cells in forming not only the follicle but also the epidermis, Cell 102 (2000), 451-461.

[116] L.A. Thoren, K. Liuba, D. Bryder, J.M. Nygren, C.T. Jensen, H. Qian, J. Antonchuk and S.E. Jacobsen, Kit regulates maintenance of quiescent hematopoietic stem cells, J Immunol 180 (2008), 2045-2053.

[117] J.E. Till and C.E. Mc, A direct measurement of the radiation sensitivity of normal mouse bone marrow cells, Radiat Res 14 (1961), 213-222.

[118] K. Tokoyoda, T. Egawa, T. Sugiyama, B.I. Choi and T. Nagasawa, Cellular niches controlling B lymphocyte behavior within bone marrow during development, Immunity $\mathbf{2 0}$ (2004), 707-718.

[119] L. Topol, X. Jiang, H. Choi, L. Garrett-Beal, P.J. Carolan and Y. Yang, Wnt-5a inhibits the canonical Wnt pathway by promoting GSK-3-independent beta-catenin degradation, $J$ Cell Biol 162 (2003), 899-908.

[120] C. van Genderen, R.M. Okamura, I. Farinas, R.G. Quo, T.G. Parslow, L. Bruhn and R. Grosschedl, Development of several organs that require inductive epithelial-mesenchymal interactions is impaired in LEF-1-deficient mice, Genes Dev 8 (1994), 2691-2703.

[121] D. Van Mater, F.T. Kolligs, A.A. Dlugosz and E.R. Fearon, Transient activation of beta -catenin signaling in cutaneous keratinocytes is sufficient to trigger the active growth phase of the hair cycle in mice, Genes Dev 17 (2003), 1219-1224. 
[122] M.T. Veeman, J.D. Axelrod and R.T. Moon, A second canon. Functions and mechanisms of beta-catenin-independent Wnt signaling, Dev Cell 5 (2003), 367-377.

[123] R. Villadsen, A.J. Fridriksdottir, L. Ronnov-Jessen, T. Gudjonsson, F. Rank, M.A. LaBarge, M.J. Bissell and O.W. Petersen, Evidence for a stem cell hierarchy in the adult human breast, J Cell Biol 177 (2007), 87-101.

[124] K.U. Wagner, C.A. Boulanger, M.D. Henry, M. Sgagias, L. Hennighausen and G.H. Smith, An adjunct mammary epithelial cell population in parous females: its role in functional adaptation and tissue renewal, Development 129 (2002), 1377-1386.

[125] K.U. Wagner, and G.H. Smith, Pregnancy and stem cell behavior. J Mammary Gland Biol Neoplasia 10 (2005) 25-36.

[126] R.L. Waikel, X.J. Wang and D.R. Roop, Targeted expression of c-Myc in the epidermis alters normal proliferation, differentiation and UV-B induced apoptosis, Oncogene 18 (1999), 4870-4878.

[127] I.L. Weissman, D.J. Anderson and F. Gage, Stem and progenitor cells: origins, phenotypes, lineage commitments, and transdifferentiations, Аппи Rev Cell Dev Biol 17 (2001), 387-403.

[128] B.E. Welm, S.B. Tepera, T. Venezia, T.A. Graubert, J.M. Rosen and M.A. Goodell, Sca-1(pos) cells in the mouse mammary gland represent an enriched progenitor cell population, Dev Biol 245 (2002), 42-56.

[129] T.A. Westfall, R. Brimeyer, J. Twedt, J. Gladon, A. Olberding, M. Furutani-Seiki and D.C. Slusarski, Wnt-5/pipetail functions in vertebrate axis formation as a negative regulator of Wnt/beta-cateniN activity, J Cell Biol 162 (2003), 889-898.

[130] R. Widelitz, Wnt signAling through canonical and noncanoniCal pathways: recent progResS, Growth Factors $\mathbf{2 3}$ (2005), 111-116.

[131] J.F. Wiesen, P. Young, Z. Werb and G.R. CunHa, Signaling through the stromAl epidermal growth factor receptor is necessary for mammary ductal development, Development $\mathbf{1 2 6}$ (1999), 335-344.
[132] A. Wilson, M.J. Murphy, T. Oskarsson, K. Kaloulis, M.D. Bettess, GM. Oser, A.C. Pasche, C. Knabenhans, H.R. Macdonald and A. Trumpp, c-Myc controls the balance between hematopoietic stem cell self-renewal and differentiation, Genes Dev 18 (2004), 2747-2763.

[133] A. Wilson and A. TrUmpp, Bone-marrow haematopoieticstEm-cell Niches, Nat Rev ImmunoL 6 (2006), 93-106.

[134] A.M. Wu, J.E. Till, L. Siminovitch and E.A. McCulloch, Cytological evidence for a relationship between normal hemotopoietic colOnY-forming cells and cells of the lymphoid system, J Exp Med 127 (1968), 455-464.

[135] T. Xie and A.C. Spradling, A niche maintaining germ line stem cells in the Drosophila ovary, Science 290 (2000), 328330.

[136] A. Yang, R. Schweitzer, D. Sun, M. Kaghad, N. Walker, R.T. Bronson, C. Tabin, A. Sharpe, D. Caput, C. Crumand F. McKeon, p63 is essential for regenerative proliferation in limb, craniofacial and epithelial development, Nature 398 (1999), 714-718.

[137] L.J. Young, D. Medina, K.B. DeOme and C.W. Daniel, The influence of host and tissue age on life span and growth rate of serially transplanted mouse mammary gland, Exp Gerontol 6 (1971), 49-56.

[138] N. Zeps, J.M. Bentel, J.M. Papadimitriou, M.F. D’Antuono and H.J. Dawkins, Estrogen receptor-negative epithelial cells in mouse mammary gland development and growth, Differentiation 62 (1998), 221-226.

[139] J. Zhang, C. Niu, L. Ye, H. Huang, X. He, W.G. Tong, J. Ross, J. Haug, T. Johnson, J.Q. Feng, S. Harris, L.M. Wiedemann, Y. Mishina and L. Li, Identification of the haematopoietic stem cell niche and control of the niche size, Nature $\mathbf{4 2 5}$ (2003), 836-841.

[140] A.J. Zhu and F.M. Watt, beta-catenin signalling modulates proliferative potential of human epidermal keratinocytes independently of intercellular adhesion, Development 126 (1999), 2285-2298. 